\title{
IDENTIFIKASI HAMA DAN PENYAKIT PADA TANAMAN PUCUK MERAH (Syzygium oleana) DI DESA NGLURAH TAWANGMANGU
}

\author{
Dwi Haryanti ${ }^{(*)}$, Laras Budyaningrum ${ }^{2)}$, Eliuta Denisa ${ }^{3)}$, Nur Rokhimah Hanik ${ }^{4)}$ \\ 1,2,3,4) Jurusan Pendidikan Biologi, FKIP, Universitas Veteran Bangun Nusantara Sukoharjo \\ *e-mail :dwiharyanti502@gmail.com
}

\begin{abstract}
The red shoot plant (Syzygium oleana) is an ornamental plant that has been developed by farmers in Nglurah Tawangmangu village. The red shoot is a herbaceous plant that has evergreen leaves, rich in phenols, antioxidant flavonoids, and betulinic acid. Pests are one of the obstacles in the effort to increase the production of ornamental plants with red shoots. There are some farmers who do not understand the types of pests that are in red shoots. This study aims to identify the types of pests that attack red shoots in Nglurah Tawangmangu village and to observe the symptoms of pest and disease attacks on red shoots. This research used observation and interview methods which were conducted in the village of Nglurah Tawangmangu on December 2-8, 2020. The tools used in this study included writing instruments, tables, and documentation tools (cellphone cameras). The variables to be observed are pests and diseases found in red shoots. The data obtained were analyzed by qualitative descriptive. The results showed that there were 2 species of disease, namely fungi that cause leaf spot Pestalotia sp, and Cercospora sp and 4 species of pests that attack red shoots, namely: Doleschallia polibete, Macrothylaricia rubi (caterpillar) Monomorium minimum (small black ants) and Tetranycus (red mites).
\end{abstract}

Key words: red shoots, pests, disease

\section{PENDAHULUAN}

Desa Nglurah merupakan salah satu desa pertanian di daerah Tawangmangu. Selain itu desa ini juga merupakan desa pariwisata karena hampir semua masyarakat disana punya budidaya tanaman hias. Selain itu potensi alamnya yang sejuk dan tanahnya yang subur sangat baik untuk budidaya tanaman hortikultura termasuk tanaman hias. Dari hasil survey, iklimnya yang cocok, kesuburan tanahnya dan potensi daerah perlintasan inilah yang dijadikan andalan bagi masyarakat di desa Nglurah yang memanfaatkan wilayahnya yang subur menjadi sentra produksi tanaman hias.

Warga desa Nglurah mulai tertarik mengembangkan usaha di sektor tanaman hias ini sejak tahun 70-an hingga terbentuknya wadah perkumpulan kelompok tani. Para anggota kelompok tani mulai aktif dalam kegiatan untuk membudidayakan tanaman hias dan masing-masing anggotanya memiliki kios tanaman hias sendiri yang terdiri dari beragam jenis, termasuk Pucuk Merah. Pucuk merah merupakan jenis tanaman perdu. Daun pada tanaman pucuk merah memiliki warna hijau kuning, orange, dan merah. Ukuran daun pucuk merah $\pm 6 \mathrm{~cm}$ dan lebar $\pm 2 \mathrm{~cm}$ dengan pertulangan daunnya menyirip, bunga majemuk tersusun dalam malai berkarang terbatas (Salsabila, 2020). Pucuk merah merupakan suatu tanaman perdu yang berdaun selalu hijau, kaya akan fenol, flavonoid antioksidan, dan asam betulinic (Aisha et al., 2013). Ciri khas dari jenis tumbuhan ini jika diremas

akan mengeluarkan roma khas kandungan minyak atsiri yang terdapat pada berbagai Syzygium (Utami, 2012)

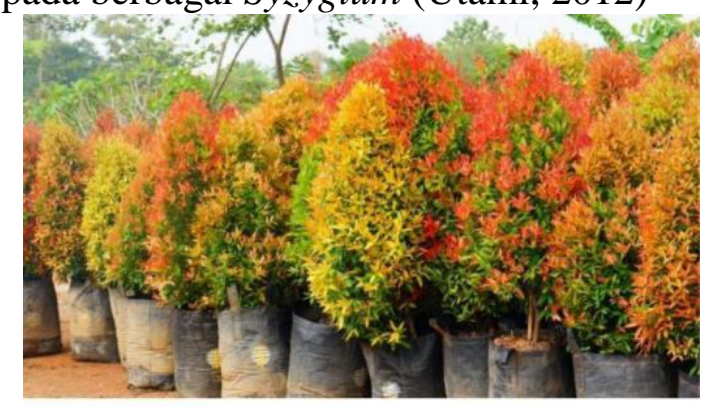

Gambar 1. Tanaman Pucuk Merah

Sumber : Budi, 2018

Tanaman pucuk merah mempunyai banyak keistimewaan dan 
fungsi. Selain dari keindahannya yang dapat dijadikan tanaman hias, tanaman pucuk merah yang kokoh dan menyimpan cadangan air dapat dijadikan sebagai tanaman penghijauan untuk mencegah tanah longsor. Dapat pula dijadikan pembatas dan pagar hidup, dan baik juga untuk merehabilitasi lahan (Mahalizikri et al., 2019). Tanaman pucuk merah dapat berfungsi untuk mengurangi kebisingan, polusi udara dan visual karena kepadatan kanopi. (Larasati et al., 2018). Petani lebih menyukai

membudidayakan tanaman hias khususnya pucuk merah, karena tingginya permintaan pembeli. Namun dalam upaya budidaya tanaman pucuk merah, banyak menemui masalah antara lain : mahalnya harga pestisida dan adanya serangan organisme pengganggu tanaman (OPT). Oleh karena itu diperlukan penelitian untuk mengidentifikasi hama dan penyakit pada pucuk merah.

Hama dan penyakit utama tanaman pucuk merah antara lain: Jamur penyebab bercak daun (Pestalotia sp, dan Cercospora sp), Doleschallia polibete, Monomorium minimum (semut hitam kecil)dan Tetranycus (tungau merah) (Sutarman, 2017).

Hama pada tanaman pucuk merah yaitu adanya hama Cercospora $s p$ dan Pestalotia sp yang merupakan jamur penyebab bercak pada daun pucuk merah. Jamur Cercospora sp tergolong dalam kelas Deuteromycetes, Ordo Moniliales, dan famili Dematiaceae (Sutarman, 2017). Jamur Pestalotia sptergolong dalam kelas Deuteromycetes dan famili Melanconiaceae. Gejala yang tampak pada daun akibat hama Cercospora sp dan Pestalotia spsama yaituadanya bercak berwarna kuning sampai coklat kemerahan, bercak tersebut akan menyatu dan menjadi lebar. Pada permukaan daun yang lain juga timbul bercak hitam yang merupakan kumpulan dari konidiofor.

Infeksi dari kedua jenis cendawan penyebab bercak merah ke coklatan pada tanaman pucuk merah tersebut diatas dapat melalui lubang alami (stomata) dan melalui luka. Selama infeksi patogen tumbuh dan memperbanyak diri dalam jaringan daun sehingga menyebabkan terhambatnya proses fotosintesis pada tanaman pucuk merah. Jika terjadi pengurangan fotosintesis akan berpengaruh terhadap laju pertumbuhan tanaman (Tomohon et al., 2016)

Selain itu ditemukan juga hama Doleschallia polibete (ulat daun)yang menyerang pada daun pucuk merah. Daun yang terserang menunjukkan gejala adanya lubang pada tepi daun akibat dari mulut penggigit dan pengunyah dari hama tersebut yang memakan daun pucuk merah. Selain ulat daun, ditemukan juga ulat bulu Macrothylaricia rubi. Ulat/ larva dari ordo Lepidoptera dan famili Lasiocamidae ini menyerang bagian daun. Daun akan berlubang dan tepi daun terkoyak dengan bekas gigitan yang tidak rata atau bergerigi dan akhirnya tinggal tulang daun yang tersisa. Hal ini akan menghambat pertumbuhan tanaman karena terganggunya proses fotosintesis (Haryanti et al., 2013).

Selain hama ulat di atas ada juga semut yang menyerang pucuk merah. Semut merupakan serangga sosial yang memiliki peranan sebagai agen pengurai bahan organik dan sebagai indikator untuk melihat pengaruh aplikasi dari pestisida di suatu area perkebunan (Triwibowo, H., Jumani \& Emawati, 2014). Namun semut dianggap juga sebagai serangga perusak karena dapat menyebabkan kerusakan pada tanaman 
Florea : Jurnal Biologi dan Pembelajarannya, 8(1), 2021, 39-47

This is an open access article under the CC-BY-SA license (https://creativecommons.org/licenses/by-sa/4.o/)

ISSN 2355-6102(print), ISSN 2502-0404(online)

DOI : 10.25273/florea.v8i1.9183

terutama masa pembungaan dan pembuahan (Bambang et al., 2019).

Tungau merah Tetranycus sp termasuk hama yang tergolong dalam ordo Acari, family Tentranychidae (M.R., 2019). Tungau dapat menyerang pada beberapa tanaman antara lain : kapas, stoberi, tomat, kedelai, kacang panjang dan tanman hias seperti bunga ros dan pucuk merah (Sasmito, 2017)

Banyak petani untuk mengendalikan OPT tersebut lebih banyak menggunakan pestisida. Namun petani kurang menyadari terjadinya dampak negatif terhadap organisme bukan sarasan seperti parasitoid dan predator dan pencemaran terhadap lingkungan. Dengan demikian penggunaan pestisida yang berlebihan dapat mengganggu kesehatan petani dengan adanya residu, polusi dan menurunkan keanekaragaman organisme di alam, yang tentunya berpengaruh pada sistem pertanian yang alami, oleh karena itu perlu adanya diidentifikasi jenis jenis hama pada pucuk merah seta diperlukan solusi unruk mengatasi hama pada tanaman pucuk merah. Adapun tujuan penelitian ini untuk mengidentifikasi jenisjenis hama yang menyerang tanaman pucuk merah di beberapa green house milik warga desa Nglurah Tawangmangu dan untuk mengamati gejala serangan hama pada tanaman pucuk merah. Penelitian ini diharapkan dapat digunakan sebagai bahan informasi bagi petani tanaman hias Nglurah pada khususnya dan pengusaha tanaman hias pada umumnya.

\section{METODE PENELITIAN}

\section{Tempat dan Waktu}

Pengamatan dilakukan di beberapa green house milik warga desa Nglurah Tawangmangu pada 2-8 Desember 2020. Ketinggian 80-2000 meter di atas permukaan laut (mdpl) suhu antara $18^{0} \mathrm{C}$ $-31^{0} \mathrm{C}$.

\begin{abstract}
Alat dan Bahan
Alat dan Bahan yang digunakan yaitu 1. Tanaman pucuk merah. 2 Gunting taman. 3 Kantong plastik transparan. 4 Kamera 5. Alat tulis.

\section{Metode Pelaksanaan}

Penelitian ini menggunakan metode observasi dan wawancara.

Pengamatan dilakukan terhadap tanaman pucuk merah yang terserang hama dan penyakit. Tanaman pucuk

merah yang terserang diamati berdasarkan gejala serangan yang diambil yaitu 10 tanaman. Jumlah Tanaman contoh yang terserang hama dan penyakit dipotong dengan gunting dan dimasukkan ke dalam kantong plastik transparan. Kemudian data hasil identifikasi dianalisis dengan deskriptif kualitatif.

\section{HASIL DAN PEMBAHASAN}

\section{Hasil Penelitian}

Tabel hasil penelitian

\begin{tabular}{|c|c|c|c|}
\hline $\begin{array}{c}\text { Nama } \\
\text { Tanaman }\end{array}$ & Gejala & Hama & Penyakit \\
\hline $\begin{array}{l}\text { Pucuk } \\
\text { Merah } 1\end{array}$ & $\begin{array}{l}\text { Bercak } \\
\text { Berwarn } \\
\text { a Kuning } \\
\text { Dan } \\
\text { Tepi } \\
\text { Daun } \\
\text { Berluban } \\
\text { g }\end{array}$ & $\begin{array}{l}\text { Ulat } \\
\text { Daun }\end{array}$ & Jamur \\
\hline $\begin{array}{l}\text { Pucuk } \\
\text { Merah } 2\end{array}$ & $\begin{array}{l}\text { Bercak } \\
\text { Berwarn } \\
\text { a } \\
\text { Kemerah } \\
\text { an Dan } \\
\text { Daun } \\
\text { Menggul } \\
\text { ung }\end{array}$ & Semut & Jamur \\
\hline $\begin{array}{l}\text { Pucuk } \\
\text { Merah } 3\end{array}$ & $\begin{array}{l}\text { Lubang } \\
\text { Tepi } \\
\text { Daun } \\
\text { Dan } \\
\text { Daun } \\
\text { Menggul } \\
\text { ung }\end{array}$ & $\begin{array}{l}\text { Ulat } \\
\text { Daun } \\
\text { Dan } \\
\text { Semut }\end{array}$ & \\
\hline
\end{tabular}


Florea : Jurnal Biologi dan Pembelajarannya, 8(1), 2021, 39-47

This is an open access article under the CC-BY-SA license (https://creativecommons.org/licenses/by-sa/4.o/) ISSN 2355-6102(print), ISSN 2502-0404(online)

DOI : 10.25273/florea.v8i1.9183

\begin{tabular}{|c|c|c|c|}
\hline $\begin{array}{l}\text { Pucuk } \\
\text { Merah } 4\end{array}$ & $\begin{array}{l}\text { Bercak } \\
\text { Kecoklat } \\
\text { an Dan } \\
\text { Lubang } \\
\text { Tepi } \\
\text { Daun } \\
\end{array}$ & $\begin{array}{l}\text { Ulat } \\
\text { Daun }\end{array}$ & Jamur \\
\hline $\begin{array}{l}\text { Pucuk } \\
\text { Merah } 5\end{array}$ & $\begin{array}{l}\text { Bercak } \\
\text { Berwarn } \\
\text { a Kuning } \\
\text { Dan } \\
\text { Tepi } \\
\text { Daun } \\
\text { Berluban } \\
\text { g } \\
\end{array}$ & $\begin{array}{l}\text { Ulat } \\
\text { Daun }\end{array}$ & Jamur \\
\hline $\begin{array}{l}\text { Pucuk } \\
\text { Merah } 6\end{array}$ & $\begin{array}{l}\text { Lubang } \\
\text { Pada } \\
\text { Daun } \\
\text { Dan } \\
\text { Daun } \\
\text { Menggul } \\
\text { ung } \\
\end{array}$ & $\begin{array}{l}\text { Ulat } \\
\text { Daun } \\
\text { Dan } \\
\text { Semut }\end{array}$ & \\
\hline $\begin{array}{l}\text { Pucuk } \\
\text { Merah } 7\end{array}$ & $\begin{array}{l}\text { Bercak } \\
\text { Kecoklat } \\
\text { an Dan } \\
\text { Daun } \\
\text { Menggul } \\
\text { ung } \\
\end{array}$ & Semut & Jamur \\
\hline $\begin{array}{l}\text { Pucuk } \\
\text { Merah } 8\end{array}$ & $\begin{array}{l}\text { Lubang } \\
\text { Tepi } \\
\text { Daun } \\
\text { Dan } \\
\text { Bercak } \\
\text { Kekunin } \\
\text { gan } \\
\end{array}$ & $\begin{array}{l}\text { Ulat } \\
\text { Daun }\end{array}$ & Jamur \\
\hline $\begin{array}{l}\text { Pucuk } \\
\text { Merah } 9\end{array}$ & $\begin{array}{l}\text { Daun } \\
\text { Menggul } \\
\text { ung Dan } \\
\text { Berluban } \\
\mathrm{g} \\
\end{array}$ & $\begin{array}{l}\text { Semut } \\
\text { Dan } \\
\text { Ulat } \\
\text { Daun }\end{array}$ & \\
\hline $\begin{array}{l}\text { Pucuk } \\
\text { Merah } 10\end{array}$ & $\begin{array}{l}\text { Bercak } \\
\text { Kecoklat } \\
\text { an Dan } \\
\text { Lubang } \\
\text { Tepi } \\
\text { Daun }\end{array}$ & $\begin{array}{l}\text { Ulat } \\
\text { Daun }\end{array}$ & Jamur \\
\hline
\end{tabular}

Hasil penelitian menunjukkan terdapat 2 spesies penyakit yaitu Jamur penyebab bercak daun Pestalotia sp, dan Cercospora $s p$ dan 4 spesies hama yang menyerang pucuk merah yaitu : Doleschallia polibete, Macrothylaricia rubi (ulat bulu) Monomorium minimum (semut hitam kecil) dan Tetranycus (tungau merah). Gejala yang tampak pada daun akibat hama Cercospora $s p$ dan Pestalotia sp sama yaituadanya bercak berwarna kuning sampai coklat kemerahan, bercak tersebut akan menyatu dan menjadi lebar. Pada permukaan daun yang lain juga timbul bercak hitam yang merupakan kumpulan dari konidiofor.

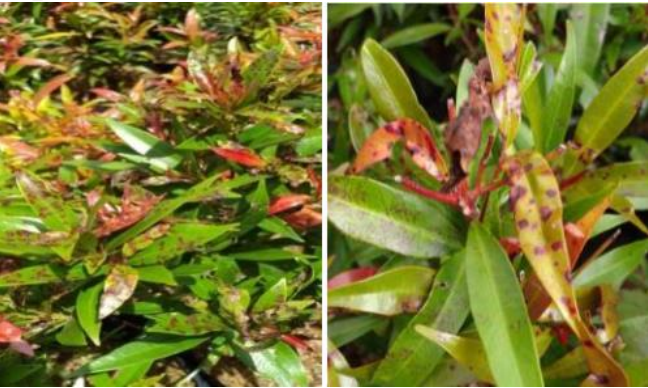

Gambar 2: Gejala serangan hama

Cercospora sp dan Pestalotia sp (koleksi pribadi)

Infeksi dari kedua jenis cendawan penyebab bercak merah ke coklatan pada tanaman pucuk merah tersebut diatas dapat melalui lubang alami (stomata) dan melalui luka. Selama infeksi patogen tumbuh dan memperbanyak diri dalam jaringan daun sehingga menyebabkan terhambatnya proses fotosintesis pada tanaman pucuk merah. Jika terjadi pengurangan fotosintesis akan berpengaruh terhadap laju pertumbuhan tanaman.

Selain itu ditemukan juga hama Doleschallia polibete (ulat daun)yang menyerang pada daun pucuk merah. Daun yang terserang menunjukkan gejala adanya lubang pada tepi daun akibat dari mulut penggigit dan pengunyah dari hama tersebut yang memakan daun pucuk merah (Gambar 3.). 


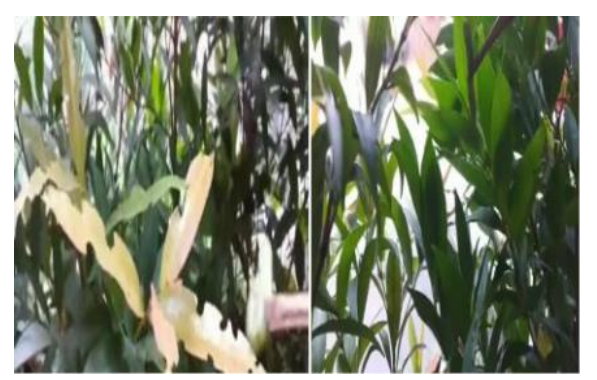

Gambar 3 : Gejala serangan hama Handeleum Doleschallia polibete (ulat daun) (koleksi pribadi)

Selain ulat daun, ditemukan juga ulat bulu Macrothylaricia rubi. Ulat/ larva dari ordo Lepidoptera dan famili Lasiocamidae ini menyerang bagian daun. Daun akan berlubang dan tepi daun terkoyak dengan bekas gigitan yang tidak rata atau bergerigi dan akhirnya tinggal tulang daun yang tersisa. Hal ini akan menghambat

pertumbuhan tanaman karena terganggunya proses fotosintesis. Ulat bulu juga merusak bagian pucuk. Hasil pengamatan langsung di lapangan ditemukan ulat bulu Macrothyl

aricia rubi yang masih kesil di bawah permukaan daun pucuk merah

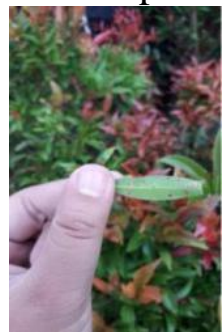

Gambar 4 : Gejala serangan hama Macrothylaricia rubi (ulat bulu) (koleksi pribadi)

Selain hama ulat di atas ada juga semut yang menyerang pucuk merah. Semut menyebabkan kerusakan pada tanaman terutama masa pembungaan dan pembuahan sehingga semut dikatakan sebagai agen pembawa

penyakit. Gejala Semut yang menyerang pucuk merah yaitu dengan cara menggulung daun di bagian pucuk tanaman sebagai tempat tinggal sehingga menghambat pertumbuhan pucuk merah.

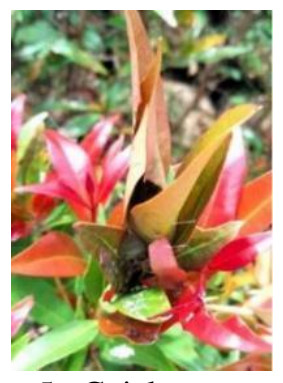

Gambar 5 : Gejala serangan hama Monomorium minimum (semut hitam kecil) (koleksi pribadi)

Tungau merah Tetranycus $s p$ termasuk hama yang tergolong dalam ordo Acari, family Tentranychidae. Tungau dapat menyerang pada beberapa tanaman antara lain : kapas, stoberi, tomat, kedelai, kacang panjang dan tanman hias seperti bunga ros dan pucuk merah

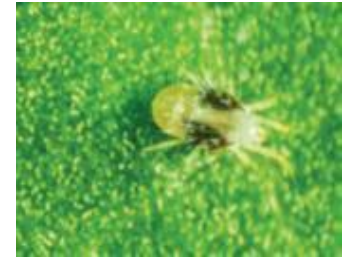

Gambar 6 : Gejala serangan hama Tetranycus sp. (Tungau) (koleksi pribadi)

\section{Pembahasan}

Dari hasil penelitian menunjukkan terdapat 2 spesies penyakit yaitu Jamur penyebab bercak daun Pestalotia sp,dan Cercospora sp dan 4 spesies hama yang menyerang pucuk merah yaitu : Doleschallia polibete, Macrothylaricia rubi (ulat bulu) Monomorium minimum (semut hitam kecil) dan Tetranycus (tungau merah).

Jamur penyebab bercak daun (Pestalotia sp, dan Cercospora sp) hal ini sesuai penelitian (Sutarman, 2017) bahwa Hama pada tanaman pucuk merah yaitu adanya hama Cercospora sp dan Pestalotia sp yang merupakan jamur penyebab bercak pada daun 
pucuk merah. Jamur Cercospora sp tergolong dalam kelas Deuteromycetes,

Ordo Moniliales, dan famili Dematiaceae.

Hama selanjutnya Doleschallia polibete (ulat daun) dan Macrothylaricia rubi. Hal ini sesuai penelitian (Haryanti et al., 2013) bahwa Doleschallia polibete (ulat daun)yang menyerang pada daun pucuk merah. Daun yang terserang menunjukkan gejala adanya lubang pada tepi daun akibat dari mulut penggigit dan pengunyah dari hama tersebut yang memakan daun pucuk merah. Selain ulat daun, ditemukan juga ulat bulu Macrothylaricia rubi. Ulat/ larva dari ordo Lepidoptera dan famili Lasiocamidae ini menyerang bagian daun. Daun akan berlubang dan tepi daun terkoyak dengan bekas gigitan yang tidak rata atau bergerigi dan akhirnya tinggal tulang daun yang tersisa. Hal ini sesui dengan penelitian (Haryanti et al., 2013). Jamur penyebab bercak daun dapat disebabkan oleh jamur dari jenis Pestalotia sp, dan Cercospora sp), Doleschallia polibete (ulat daun).

Hama yang selanjutnya Monomorium minimum (semut hitam kecil), Tetranycus (tungau merah) dan Macrothylaricia rubi (ulat bulu) Hal ini sesuai dengan penelitian Triwibowo 2014 bahwa Semut merupakan serangga sosial yang memiliki peranan sebagai agen pengurai bahan organik dan sebagai indikator untuk melihat pengaruh aplikasi dari pestisida di suatu area perkebunan. Namun semut dianggap juga sebagai serangga perusak karena dapat menyebabkan kerusakan

pada tanaman terutama masa pembungaan dan pembuahan.

Tungau merah Tetranycus $s p$ termasuk hama yang tergolong dalam ordo Acari, family Tentranychidae. Tungau dapat menyerang pada beberapa tanaman antara lain : kapas, stoberi, tomat, kedelai, kacang panjang dan tanman hias seperti bunga ros dan pucuk merah hal ini sesuai literature (Sasmito, 2017).

\section{KESIMPULAN}

Hama dan penyakit yang terdapat pada tanaman pucuk merah terdiri dari 2 spesies penyakit yaitu Jamur penyebab bercak daun Pestalotia sp,dan Cercospora sp dan 4 spesies hama yang menyerang pucuk merah yaitu : Doleschallia polibete, Macrothylaricia rubi (ulat bulu) Monomorium minimum (semut hitam kecil) dan Tetranycus (tungau merah).

Gejala serangan Pestalotia sp, dan Cercospora $s p$ ditandai dengan adanya bercak coklat kehitaman pada permukaan daun. Gejala serangan

Doleschallia polibetedan Macrothylaricia rubi. Yaitu daun akan berlubang dan tepi daun terkoyak dengan bekas gigitan yang tidak rata atau bergerigi dan akhirnya tinggal tulang daun yang tersisa. Gejala

serangan Monomorium minimum ditandai dengan pucuk daun yang paling muda menggulung sebagai tempat tinggal semut, sedangkan gejala serangan Tetranycus bagian permukaan atas daun berwarna coklat kemerahan. Diperlukan penelitian lanjutan dengan sampel yang lebih banyak untuk identifikasi hama dan penyakit.

\section{UCAPAN TERIMA KASIH}

Ucapan terima kasih kami sampaikan kepada ibu Dra. Nur Rokhimah Hanik M.P selaku dosen pembimbing, Pendidikan Biologi, Universitas Veteran Bangun Nusantara Sukoharjo yang telah memberikan bimbingan selama penelitian di desa Nglurah Tawangmangu, warga desa Nglurah Tawangmangu serta teman mahasiswa yang telah membantu 
Florea : Jurnal Biologi dan Pembelajarannya, 8(1), 2021, 39-47

This is an open access article under the CC-BY-SA license (https://creativecommons.org/licenses/by-sa/4.o/) ISSN 2355-6102(print), ISSN 2502-0404(online)

DOI : 10.25273/florea.v8i1.9183

pelaksanaan penelitian dari awal hingga akhir. 


\section{DAFTAR PUSTAKA}

Aisha, A. F. A., Ismail, Z., Abu-Salah, K. M., Siddiqui, J. M., Ghafar, G., \& Abdul Majid, A. M. S. (2013). Syzygium campanulatum korth methanolic extract inhibits angiogenesis and tumor growth in nude mice. BMC Complementary and Alternative Medicine, 13(May 2014).

https://doi.org/10.1186/1472-688213-168

Azwanida, NN. 2015. A Review on the Extraction Methods Use in Medicinal Plants, Principle, Strength and Limitation. Med Aromat Plants 2015.

Bambang, Y., Diba, F., \& Anwari, S. (2019). Identifikasi Serangga Dan Penyakit Di Areal Persemaian Pt. Sari Bumi Kusuma Di Kecamatan Bukit Raya Kabupaten Katingankalimantan Tegah. Jurnal Hutan Lestari, 7(3), 1478-1485. https://jurnal.untan.ac.id/index.php /jmfkh/article/download/37624/75 676584040

Ghosh, M. dan Singh,S.P. 2015. A Review on Phytoremediation of Heavy Metals and Utilization of its Byproducts. Applied Ecology and Environmental Research 3 (1): 1 18.

Haryanti, D., Budianta, D., \& Salni, S. (2013). Potensi Beberapa Jenis

Tanaman Hias sebagai Fitoremediasi Logam Timbal $(\mathrm{Pb})$ dalam Tanah. Jurnal Penelitian Sains, $\quad 16(2), \quad 168122$. http://ejurnal.mipa.unsri.ac.id/inde x.php/jps/article/view/72

Larasati, E. D., Euis Elih Nurlaelih, \&
Sitawati. (2018). Tanggap Pertumbuhan Dan Warna Daun Pucuk Merah (Syzygium oleana) Pada Dosis Pupuk Mgso4 Dan Tingkat Naungan. Jurnal Produksi Tanaman, 6(9), 2094-2102. http://protan.studentjournal.ub.ac.i $\mathrm{d} /$ index.php/protan/article/view/88 4

Leekha, S. , Terrel, C. L., Edson, R. S. 2011. General Principles of Antimicrobial Therapy. Symposium On Antimicrobial Therapy.

Lahudin. 2017. Aspek Unsur Makro dalam Kesuburan Media. Medan. USU press.

M.R., A. W. (2019). Merawat Tanaman Hias. In A. W. M.R. (Ed.), Journal of Chemical Information and Modeling (Vol. 53, Issue 9). CV. Sinar Cemerlang Abadi. http://ebook.pustaka.sumbarprov.g o.id/index.php? $\mathrm{p}=$ fstreampdf $\&$ fid $=276 \&$ bid $=256$

Mahalizikri, I. F., Ekonomi, P., \& Sepotong, D. (2019). Membangun Masyarakat Desa Melalui Tanaman Pucuk Merah Pada Unit Usaha Bumdes. 8(1), 89-100.

Novizan. 2013. Petunjuk Pemakaian Pestisida. Agro Media Pustaka. Jakarta.

Salsabila, F. S. (2020). Efektivitas Ekstrak Daun Pucuk Merah (Syzygium myrtifolium Walp.) Sebagai Antimikroba Terhadap Salmonella typhi. 1-72. http://etheses.uinmalang.ac.id/21887/

Sasmito, G. W. (2017). Sistem Pakar 
Diagnosis Hama dan Penyakit Tanaman Hortikultura dengan Teknik Inferensi Forward dan Backward Chaining. 5(April), 6974. https://doi.org/10.14710/jtsiskom.5 .2.2017.69-74

Sutarman.

(2017). Dasar-Dasar Ilmu

Penyakit Tanaman (Sutarman (ed.)). UMSIDA PRESS. http://eprints.umsida.ac.id/4208/1/ Buku Dasar-Dasar Ilmu Penyakit Tanaman.pdf

Tomohon, K. K., Mamahit, J. M. E., \& Manueke, J. (2016). Pengendalian Hama Terpadu Tanaman Hias Di Desa Kakaskasen Kota Tomohon ( Jenis-Jenis Hama Pada Tanaman Krisan Di Desa. 3, 81-94.

Triwibowo, H., Jumani \& Emawati, H. (2014). Identifikasi Hama Dan Penyakit Shorea Leprosula Miq Di Taman Nasional Kutai Resort Sangkima Kabupaten Kutai Timur Provinsi Kalimantan Timur. Jurnal Agrifor, XIII(August 2012), 175$184 . \quad$ http://ejurnal.untagsmd.ac.id/index.php/AG/article/vie w/860

Utami, E. R. (2012). Antibiotika, Resistensi, Dan Rasionalitas Terapi. El-Hayah, 1(4), 191-198. https://doi.org/10.18860/elha.v1i4. 1783 